J. Dairy Sci. 96:3573-3587

http://dx.doi.org/10.3168/jds.2012-5759

(C) American Dairy Science Association ${ }^{\circledR}, 2013$.

\title{
Effect of the level of maternal energy intake prepartum on immunometabolic markers, polymorphonuclear leukocyte function, and neutrophil gene network expression in neonatal Holstein heifer calves ${ }^{1}$
}

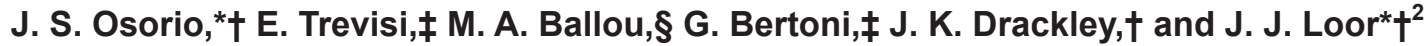 \\ *Mammalian NutriPhysioGenomics, and \\ †Department of Animal Sciences, University of Illinois, 1207 West Gregory Drive, Urbana 61801 \\ łlstituto di Zootecnica, Facoltà di Agrarià, Università Cattolica del Sacro Cuore, 29122 Piacenza, Italy \\ §Department of Animal \& Food Sciences, Texas Tech University, Lubbock 79409
}

\begin{abstract}
A conventional approach in dairy cow nutrition programs during late gestation is to feed moderate-energy diets. The effects of the maternal plane of nutrition on immune function and metabolism in newborn calves are largely unknown. Holstein cows $(\mathrm{n}=20)$ were fed a controlled-energy $(\mathrm{CON})$ diet $(1.24 \mathrm{Mcal} / \mathrm{kg})$ for the entire dry period $(\sim 50 \mathrm{~d})$ or the $\mathrm{CON}$ diet during the first $29 \mathrm{~d}$ of the dry period followed by a moderateenergy (OVE) diet (1.47 Mcal/kg) during the last $21 \mathrm{~d}$ prepartum. All calves were weighed at birth before first colostrum intake. Calves chosen for this study $(\mathrm{n}=6$ per maternal diet) had blood samples harvested before colostrum feeding (d 0) and at 2 and $7 \mathrm{~d}$ of age. Blood samples were used to determine metabolites, acutephase proteins, oxidative stress markers, hormones, phagocytic capacity of polymorphonuclear leukocytes (PMN) and monocytes, and total RNA was isolated from PMN. Calves from OVE dams weighed, on average, $5 \mathrm{~kg}$ less at birth (44.0 vs. $48.6 \mathrm{~kg})$ than calves from CON dams. Blood glucose concentration in OVE calves had a more pronounced increase between 0 and $2 \mathrm{~d}$ than $\mathrm{CON}$, at which point phagocytosis by PMN averaged $85 \%$ in OVE and $62 \%$ in CON. Compared with CON, calves from OVE had greater expression of $T L R 4$, but lower expression of PPARA and PPARD at birth. Expression of $P P A R G$ and $R X R A$ decreased between 0 and $2 \mathrm{~d}$ in both groups. Concentrations of leptin, cholesterol, ceruloplasmin, reactive oxygen metabolites, myeloperoxidase, retinol, tocopherol, IgG, and total protein, as well as expression of SOD2 and SELL increased markedly by $2 \mathrm{~d}$ in both groups; whereas, cortisol, albumin, acid-soluble protein, NEFA, insulin,
\end{abstract}

Received May 22, 2012

Accepted February 22, 2013.

${ }^{1}$ Supported by Hatch funds under project ILLU-538-326 (National Institute of Food and Agriculture).

${ }^{2}$ Corresponding author: jloor@illinois.edu as well as expression of IL6,TLR4,IL1R2, LTC4S, and $A L O X 5$ decreased by $2 \mathrm{~d}$. By $7 \mathrm{~d}$ of age, the concentration of haptoglobin was greater than precolostrum and was lower for OVE than CON calves. Our data provide evidence for a carry-over effect of maternal energy overfeeding during the last 3 wk before calving on some measurements of metabolism in the calf at birth and the phagocytic capacity of blood neutrophils after colostrum feeding. It might be feasible to design nutrient supplements to fortify colostrum in a way that metabolic and immunologic capabilities of the calf are improved.

Key words: fetal programming, transcriptomics, nutrition, dairy cow

\section{INTRODUCTION}

Hormones such as insulin play a key role during gestation in dictating the partitioning of dietary nutrients between mother and fetus. As in humans, cows in late lactation redirect glucose, a major nutrient required for fetal growth, from peripheral tissues to the placenta (Newbern and Freemark, 2011), that is, they experience a pseudodiabetic state. Human and rat studies reported that influence of the pituitary on fetal growth might be overridden by hormones, such as growth hormone, lactogen, and leptin (Farley et al., 2010; Newbern and Freemark, 2011). As such, endocrine peripheral changes directly or indirectly affected by placenta can, in turn, determine the fate of nutrients and ensuing metabolic changes (Newbern and Freemark, 2011).

Transition cow nutrition has been the subject of extensive research and several recent experiments have examined how the prepartal level of energy intake can affect early lactation performance of cows (Rabelo et al., 2003; Hayirli et al., 2011; Janovick et al., 2011). Interestingly, overfeeding energy to cows as late as d 21 before parturition triggered a robust upregulation of lipogenic gene expression in adipose tissue without dampening signaling through the pathway (Ji et al., 
2012), suggesting that insulin sensitivity may not be impaired by the hyperinsulinemic response to overfeeding energy (Janovick et al., 2011; Ji et al., 2012). If that scenario holds true, it could mean that glucose and other nutrients (e.g., acetate, essential FA, AA) may be partly channeled to the cow's adipose depots.

Maternal overfeeding in sheep has been associated with type 2 diabetes, hypertension, and fetal growth retardation in the offspring (Wallace et al., 1999; Wang et al., 2010). To our knowledge, prepartal maternal nutrition effects on early life performance of newborn calves have been evaluated primarily through observational data, such as morbidity and mortality (Quigley and Drewry, 1998). Recently Gao et al. (2012) observed that calves born to cows underfed energy had low birth BW as well as decreased immune and antioxidant function.

Understanding how markers of stress and inflammation change during the neonatal period and are affected by prenatal nutrition can help researchers develop strategies to ameliorate the initial stress of birth (Bertoni et al., 2009). Transcriptomics have been used in recent years to gain a better understanding of the molecular mechanisms controlling basic functions of immune cells during stressful periods (Weber et al., 2006; Moyes et al., 2010). Though the nutritional physiology of the neonatal calf has been well-studied (Blum, 2006), the extent to which prenatal energy nutrition of the dam affects the profiles of stress and inflammatory markers, metabolites, and polymorphonuclear leukocyte (PMN) function and gene expression in neonatal calves are yet to be defined.

Our hypothesis was that the level of energy intake of cows during late gestation could affect neonatal immune and metabolic markers. The objective of this study was to conduct an initial evaluation of feeding a moderate-energy diet during the last $21 \mathrm{~d}$ prepartum on metabolite, hormonal, and gene expression profiles of blood PMN and link that information with PMN function during the neonatal period.

\section{MATERIALS AND METHODS}

The Institutional Animal Care and Use Committee (IACUC) of the University of Illinois approved all procedures for this study (protocol \#09214). The experiment was conducted as a randomized complete block design with 20 multiparous Holstein cows assigned randomly $(\mathrm{n}=10 /$ diet $)$ to either a controlled energy diet (CON; high-straw) with $1.24 \mathrm{Mcal}$ of $\mathrm{NE}_{\mathrm{L}} / \mathrm{kg}$ of DM or a 2-step moderate-energy close-up diet (OVE) with 1.47 Mcal of $\mathrm{NE}_{\mathrm{L}} / \mathrm{kg}$ of DM. A subset of calves from those cows $(\mathrm{n}=6 /$ group) was recruited at calving if they fulfilled the enrollment criteria explained below
Table 1. Summary of excluded calves born to cows fed a controlledenergy diet (CON; $1.24 \mathrm{Mcal} / \mathrm{kg}$ of DM) during the dry period or a controlled-energy diet followed by a moderate-energy (OVE; 1.47 $\mathrm{Mcal} / \mathrm{kg}$ ) diet during the last $21 \mathrm{~d}$ prepartum

\begin{tabular}{|c|c|c|}
\hline \multirow[b]{2}{*}{ Item } & \multicolumn{2}{|c|}{ Treatment } \\
\hline & $\mathrm{CON}$ & OVE \\
\hline Cows $(n)$ & 10 & 10 \\
\hline Twins & 1 & 2 \\
\hline Dystocia & 0 & 1 \\
\hline Low colostrum yield $<3.8 \mathrm{~L}$ & 3 & 0 \\
\hline Low colostrum quality ${ }^{1}$ & 1 & 0 \\
\hline Suckling calf ${ }^{2}$ & 0 & 1 \\
\hline
\end{tabular}

${ }^{1}$ Quality $=<60 \mathrm{mg} / \mathrm{L}$ of $\mathrm{IgG}$.

${ }^{2}$ Calf started suckling before taking precolostrum blood sample.

(Table 1). Ingredient composition of the prepartal diets, as well as animal husbandry and feeding management, were reported by Ji et al. (2012). Cows in both groups were fed the CON diet during the far-off period ( -50 to $-21 \mathrm{~d}$ relative to calving). During the close-up period $(-21 \mathrm{~d}$ to parturition) cows were assigned to either CON or OVE dietary treatments.

\section{Heifer Calf Enrollment Criteria}

Variability of cow or calf pairs was minimized by applying the following inclusion criteria: (1) calving difficulty score $<3$, (2) single calf, (3) colostrum quality assessed by hydrometer of $>60 \mathrm{mg} / \mathrm{L}$ of IgG (estimated based on specific gravity), (4) colostrum intake from the same dam at $3.8 \mathrm{~L}$, and (5) calf birth weight $>36$ $\mathrm{kg}$ (Johnson et al., 2007). On d 2 and 7 calves were bled $\sim 3 \mathrm{~h}$ after feeding.

\section{Animal Management}

Cows were housed in a ventilated enclosed barn during the dry period (the photoperiod was $8 \mathrm{~h}$ of light to $16 \mathrm{~h}$ of dark) and had access to sand-bedded freestalls until $5 \mathrm{~d}$ before expected calving date, when they were moved to an individual maternity pen bedded with straw. After parturition, cows were moved within $2 \mathrm{~h}$ to an individual chute and then milked with a portamilker vacuum pump (Nasco, Fort Atkinson, WI; Cat. no. Z15664N). Colostrum volume was recorded and IgG content was estimated based on specific gravity with a bovine colostrometer (Nasco; Cat. no. C10978N).

Calves were processed within $2 \mathrm{~h}$ after calving; calf handling included weighing, navel disinfection with a $7 \%$ tincture of iodine solution (First Priority Inc., Elgin, IL), and vaccination with TSV II (Pfizer Inc., New York, NY) via nostril application. Subsequently, calves were moved to individual pens bedded with straw, bled, and fed $3.8 \mathrm{~L}$ of first milking colostrum 
from the respective dam. Calves were offered first milk colostrum again on the second feeding at $4 \mathrm{~h}$ after birth if colostrum intake had not reached the $3.8 \mathrm{~L}$ required. A milk replacer (Advance Excelerate, Milk Specialties, Carpentersville, IL; $28.5 \%$ CP, $15 \%$ fat) was provided at a rate of $680 \mathrm{~g} / \mathrm{d}$ after colostrum consumption during the first week of age. Calves had ad libitum access to starter grain $(19.9 \% \mathrm{CP}, 13.5 \% \mathrm{NDF})$ beginning at $2 \mathrm{~d}$ of age. During the first week of age calves were housed in individual maternity pens bedded with straw.

\section{Sample Collection}

Blood samples were collected from the jugular vein using 20-gauge BD Vacutainer needles (Becton Dickinson, Franklin Lakes, NJ) before receiving colostrum (baseline), $2 \mathrm{~d}$ after receiving colostrum for the first time, and $7 \mathrm{~d}$ after birth. During the first sampling (baseline, precolostrum) $180 \mathrm{~mL}$ of total blood were collected by vacutainer $(5 \mathrm{~mL}$, BD Vacutainer, Becton Dickinson) containing serum clot activator, sodium heparin, or solution A of trisodium citrate, citric acid, and dextrose (ACD). After blood collection, tubes with $\mathrm{ACD}$ and sodium heparin were placed on ice and tubes with clot activator were kept at $21^{\circ} \mathrm{C}$ until centrifugation $(\sim 30 \mathrm{~min})$. Serum and plasma were obtained by centrifugation of clot activator and sodium heparin tubes, respectively, at $1,900 \times g$ for $15 \mathrm{~min}$. Prior to centrifugation, a total of $300 \mu \mathrm{L}$ of heparinized whole blood was used to determine the phagocytic capacity of leukocytes. Serum or plasma was used according to the manufacturer's specifications for determination of blood metabolites, acute-phase proteins, hormones, and IgG. The RNA from PMN was harvested from 170 $\mathrm{mL}$ of blood in ACD vacutainers (Moyes et al., 2010). Subsequent blood samples on 2 and $7 \mathrm{~d}$ were collected and processed as above.

\section{Blood Metabolites and Hormones}

Concentrations of IgG, BHBA, NEFA, total protein (TP), glucose, and albumin were analyzed using commercial kits at the Veterinary Diagnostics Laboratory, College of Veterinary Medicine, University of Illinois. Concentration of insulin was analyzed using a commercial kit from Mercodia (cat. no. 10-1201-01). Concentrations of cortisol, haptoglobin (HP), and acid-soluble protein were analyzed according to a previous protocol (Hulbert et al., 2011). Triacylglycerol, fibroblast growth factor 21 (FGF-21; bovine), and leptin (bovine) concentrations were determined using commercial kits from Wako (cat. no. 290-63701; Richmond, VA), BioVendor Inc. (cat. no. RD291108200R; Asheville, NC), and Cusabio (cat. no. CSB-E06771b; Wuhan, China), respectively. Alkaline phosphatase (ALP), cholesterol, ceruloplasmin, reactive oxygen metabolites (ROM), myeloperoxidase (MPO), retinol, and tocopherol were determined as previously described (Bionaz et al., 2007). The activity of MPO was determined via colorimetry (Bradley et al., 1982) based on the reaction of MPO contained in the plasma sample with hydrogen peroxide, which forms $\mathrm{H}_{2} \mathrm{O}$ and $\mathrm{O}^{-}$; the $\mathrm{O}^{-}$dianisidine dihydrochloride, an electron donor, reacts with the $\mathrm{O}^{-}$, releasing $\mathrm{H}_{2} \mathrm{O}$ and a colored compound.

\section{Apparent Efficiency of Immunoglobulin Absorption}

Colostrum IgG was measured using a kit from Zeptometrix (cat. no. 0801198; Franklin, MA). Apparent efficiency of absorption was estimated by measuring the $\operatorname{IgG}$ content in both first milking colostrum and calf serum at $48 \mathrm{~h}$ after colostrum ingestion. Apparent efficiency of absorption was calculated as plasma IgG $(\mathrm{g} / \mathrm{L}) \times$ plasma volume $(\mathrm{L}) / \mathrm{IgG}$ intake $(\mathrm{g})$ (Quigley et al., 2002).

\section{Whole Blood Phagocytosis}

Complete details are presented in Supplemental Materials. The phagocytic capacity of PMN isolated from heparinized whole blood was determined using the Phagotest kit (Orpegen Pharma, Heidelberg, Germany) following the manufacturer's instructions. In brief, 20 $\mu \mathrm{L}$ of bacteria Escherichia coli was added to 1 of 3 whole blood samples $(100 \mu \mathrm{L})$ in test tubes (Falcon, Becton Dickinson) and incubated for 10 min at $37^{\circ} \mathrm{C}$. The cells were resuspended in $200 \mu \mathrm{L}$ of DNA-staining solution, and light-protected in an ice bath until analyzed by flow cytometry (LSR II, Becton Dickinson, San Jose, CA).

\section{PMN Isolation}

Neutrophils were isolated based on procedures described by (Moyes et al., 2010) with modifications. Briefly, blood collected in ACD Vacutainer tubes was mixed well by inversion and placed on ice until isolation. Samples were centrifuged at $600 \times g$ for 30 min at $4^{\circ} \mathrm{C}$. The plasma, buffy coat, and approximately one-third of the red blood cells were removed and discarded. The remaining sample was poured into a $50-\mathrm{mL}$ conical tube (Fisher Scientific, Pittsburgh, PA). Twenty-five milliliters of deionized water at $4^{\circ} \mathrm{C}$ was added to lyse red blood cells, followed by addition of $5 \mathrm{~mL}$ of $5 \times$ PBS at $4^{\circ} \mathrm{C}$ to restore an iso-osmotic environment. Samples were centrifuged at $200 \times g$ for $10 \mathrm{~min}$ at $4^{\circ} \mathrm{C}$ and the supernatants were decanted. The pellet was washed with $10 \mathrm{~mL}$ of $1 \times$ PBS and centrifuged for $5 \mathrm{~min}(200$ 
$\times g$ at $4^{\circ} \mathrm{C}$ ) and the supernatants were decanted. Eight milliliters of deionized water at $4^{\circ} \mathrm{C}$ was added, followed by addition of $2 \mathrm{~mL}$ of $5 \times \mathrm{PBS}$ at $4^{\circ} \mathrm{C}$. Samples were centrifuged at $500 \times g$ for 5 min at $4^{\circ} \mathrm{C}$ and the supernatants were decanted. Two subsequent washings using $10 \mathrm{~mL}$ of $1 \times \mathrm{PBS}$ at $4^{\circ} \mathrm{C}$ were performed with samples centrifuged at $500 \times g$ for $5 \mathrm{~min}$ at $4^{\circ} \mathrm{C}$ and supernatants decanted. Neutrophils were immediately homogenized in $2 \mathrm{~mL}$ of Trizol Reagent (Invitrogen, Carlsbad, CA) with $1 \mu \mathrm{L}$ of liner acrylamide (Ambion Inc., Austin, TX) using a Polytron power homogenizer at maximum speed. The suspension was transferred equally into 2 RNA-free microcentrifuge tubes $(2 \mathrm{~mL}$; Fisher Scientific) and stored at $-80^{\circ} \mathrm{C}$ until further analysis.

\section{RNA Isolation, Primer Design and Evaluation, and Quantitative PCR}

Complete details are presented in Supplemental Materials. Primers were selected and evaluated based on key biological functions: inflammatory and oxidative stress response, inflammatory regulators, receptors, and transcription regulators (Supplemental Table 2, available online at http://www.journalofdairyscience. org/). All sequences were confirmed using the National Center for Biotechnology Information and the University of California, Santa Cruz's cow Genome Browser Gateway and are shown in Supplemental Table 3 (available online at http://www.journalofdairyscience.org/). For this study we used GAPDH, ribosomal protein S9 (RPS9), and ubiquitously-expressed transcript (UXT) as internal control genes, which were verified as suitable in previous publications from our research group (Piantoni et al., 2008; Kadegowda et al., 2009).

\section{Statistical Analysis}

Data were analyzed with the Proc MIXED procedure of SAS 9.2 (SAS Institute Inc., Cary, NC). Fixed effects in the model were diet, time, and diet $\times$ time. Random effect was calf within diet. The exponential correlation covariance structure SP for repeated measures was used for analysis of immunometabolites and gene expression. Blood metabolites and gene expression results were log-scale transformed if needed to comply with normal distribution of residuals, and subsequently back-transformed. Least squares means separation among sampling days were 0 and $2 \mathrm{~d}$ and 0 and $7 \mathrm{~d}$ and were performed using the $P$-diff statement. Significance was declared at $P \leq 0.10$.

\section{RESULTS}

\section{Birth Weight and Apparent Efficiency of Absorption}

Calf birth weight was affected by maternal diet $(P$ $=0.05)$, where CON (48.6 kg) calves weighed ap- proximately $5 \mathrm{~kg}$ more than OVE $(44.0 \mathrm{~kg})$ calves. This effect, however, was not statistically significant $(P=$ 0.18 ) when all calves monitored for inclusion in the study were analyzed together. Calves in CON averaged $47.9 \mathrm{~kg}$, compared with $45.7 \mathrm{~kg}$ for OVE calves. In contrast with calf birth weight, colostrum IgG was not affected $(P=0.78)$ by maternal diet and averaged 81.3 $\pm 9.2 \mathrm{mg}$ of $\mathrm{IgG} / \mathrm{mL}$. Similarly, apparent efficiency of absorption was not affected $(P=0.93)$ by maternal diet, averaging $35.3 \pm 10.9 \%$. Similar to colostrum IgG, the length of gestation was not affected $(P=0.58)$ by maternal diet. Average gestation time was $271.5 \pm 1.4$ $\mathrm{d}$ for cows fed CON and $270.3 \pm 1.4 \mathrm{~d}$ for cows fed OVE.

\section{Hormones and Growth Factors}

Main effects and interactions for hormones were not different $(P>0.10)$ except for a time effect $(P=0.04)$ observed for leptin (Figure 1A) with lower precolostrum concentration compared with 2 and $7 \mathrm{~d}$ regardless of diet. In contrast to the response in leptin, no diet, time, or diet $\times$ time interaction effect was observed for insulin and FGF-21.

\section{Metabolites}

Main effects of diet, time, and interactions for metabolites are shown in Figure 2. Glucose concentration was greater (diet $P=0.01$ ) overall in OVE calves namely due to the response on d 2 after colostrum consumption, at which point concentration was 35.8 $\mathrm{mg} / \mathrm{dL}$ greater than CON (Figure 2A). Total protein (Figure 2B; $P=0.001$ ), IgG (Figure 2C; $P=0.006$ ), and cholesterol (Figure 2D; $P<0.001$ ) were greater on d 2 and 7 than $d 0$ in both groups. In contrast, NEFA (Figure 2E; $P<0.001$ ) and the NEFA to insulin ratio (Figure 2F; $P=0.05$ ) were lower on $\mathrm{d} 2$ and 7 than $\mathrm{d}$ 0 regardless of dietary treatment. The concentrations of BHBA (Figure 2G) and triacylglycerol (Figure 2H) were not affected by the maternal diet.

\section{Stress and Inflammation Markers}

Main effects of diet and interactions for stress- and inflammation-related markers are shown in Figure 3. The lower $(P=0.07)$ overall concentration of HP in OVE than CON calves was due to a lower $(P=0.004)$ concentration in OVE at d 7 (Figure 3A). In contrast, ALP (Figure 3B) tended to be greater $(P=0.11)$ in OVE calves than CON. Both ALP $(P=0.001)$ and ceruloplasmin (Figure 2C; $P<0.001$ ) increased from birth to $\mathrm{d} 7$ in all calves. Unlike ALP and ceruloplasmin, acid-soluble protein (Figure 3D; $P<0.001$ ) and 

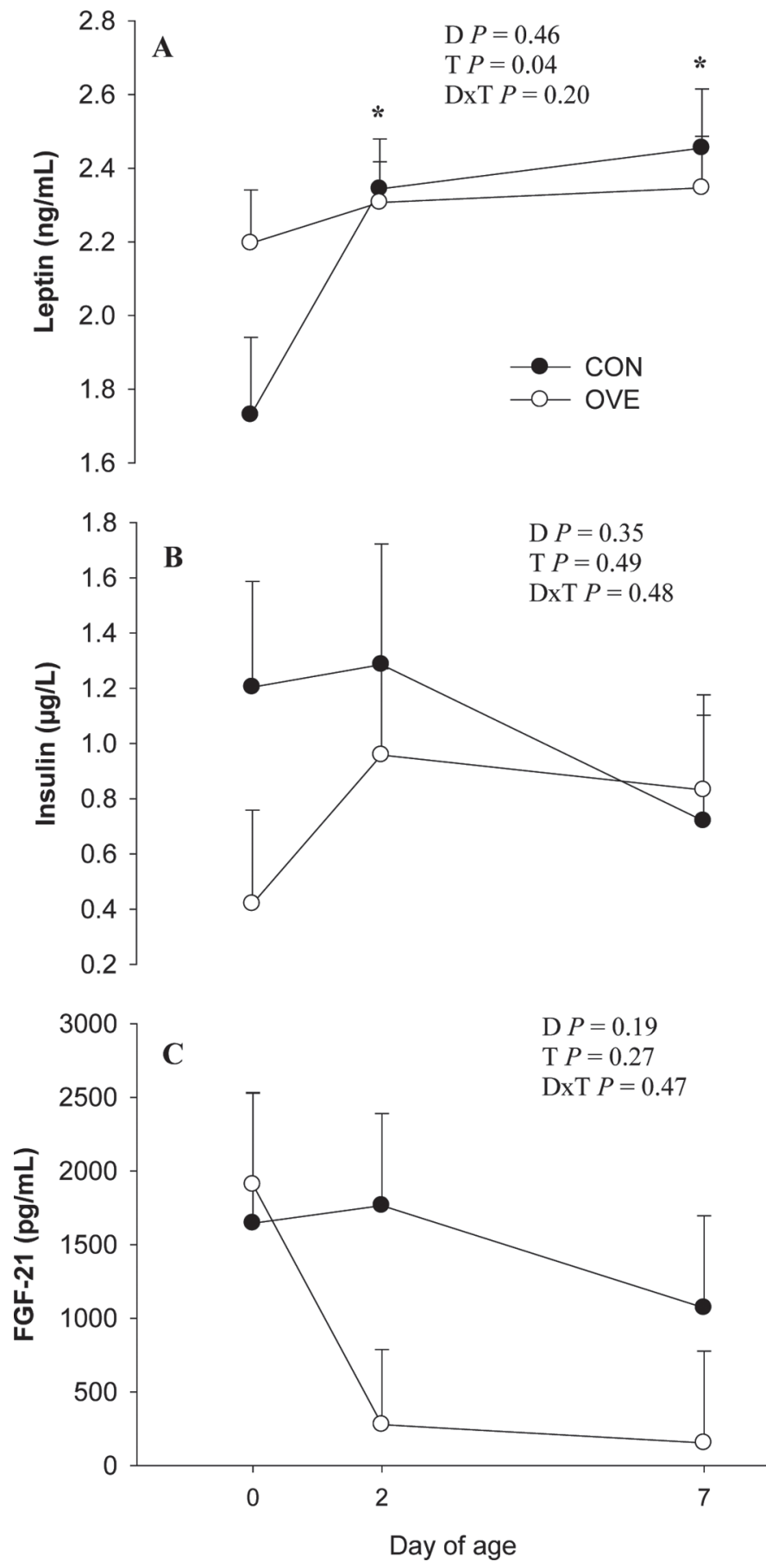

Figure 1. Blood hormones and cytokines in calves born to dams fed a conventional diet $(\mathrm{CON}=1.24 \mathrm{Mcal} / \mathrm{kg}$ of $\mathrm{DM})$ during the entire dry period or overfed a moderate energy diet $(\mathrm{OVE}=1.47 \mathrm{Mcal} / \mathrm{kg}$ of DM) during the last $21 \mathrm{~d}$ prepartum. Data are from samples at birth (precolostrum; d 0), d 2 (postcolostrum), and d 7 of age. The $P$-values for the main effect of diet (D) and time $(\mathrm{T})$ and $\mathrm{D} \times \mathrm{T}$ are shown. Mean separation between time points was evaluated via contrasts: $\mathrm{d}$ 0 versus 2 or d 0 versus 7 . Significant differences between times $(P<$ $0.10)$ are denoted by an asterisk. FGF-21 = fibroblast growth factor 21. cortisol (Figure 3E; $P=0.001$ ) decreased from 0 to $7 \mathrm{~d}$ regardless of treatment. Albumin decreased $(P<$ 0.01 ) from birth to $2 \mathrm{~d}$; however, by $7 \mathrm{~d}$ it returned to concentrations observed at birth.

\section{Oxidative Stress}

Main effects of diet, time, and interactions for oxidative stress-related markers are shown in Figure 4. Although concentrations of ROM (Figure 4A), MPO (Figure 4B), retinol (Figure 4C), and tocopherol (Figure 4D) were not affected by maternal diet, a consistent increase $(P<0.05)$ in concentration was observed for all these markers from 0 to $7 \mathrm{~d}$.

\section{Phagocytosis}

Main effects of diet, time, and interactions for phagocytosis capacity of PMN and monocytes are shown in Figure 5. Phagocytosis by leukocytes and differential analysis of leukocytes are presented in Supplemental Figures 1 and 2 (available online at http://www.journalof dairyscience.org/). Phagocytosis by PMN (Figure 5A) was greater $(P=0.04)$ in OVE calves and increased over time $(P<0.001)$. That response was associated with differences $(P=0.11)$ observed on $\mathrm{d} 2$, which were consistent with an increase $(\mathrm{P}=0.03)$ on $\mathrm{d} 2$ compared with $\mathrm{d} 0$ in OVE calves, whereas no change $(P=0.56)$ was observed in CON calves. Phagocytosis by monocytes was not affected by diet, time, or diet $\times$ time.

\section{Gene Expression}

Inflammatory and Oxidative Stress Genes. Main effects of diet, time, and interactions for inflammatory and oxidative stress-related genes are shown in Figure 6. The time effect $(P=0.09)$ for the expression of SOD2 was associated with an increase $(P=0.03)$ in its expression from 0 to $2 \mathrm{~d}$, with a return to initial values on $\mathrm{d} 7$. Although the same pattern $(P=0.02)$ was observed in CON calves from 0 to $2 \mathrm{~d}$, the expression in OVE calves remained unchanged, but that response did not reach statistical significance $(P=0.18)$. Contrary to SOD2, the expression of $L T C 4 S$ decreased ( $P$ $=0.03$ ) from 0 to $2 \mathrm{~d}$ and returned to initial levels on $\mathrm{d}$ 7 , resulting in an overall time effect $(P=0.09)$. Similar to SOD2 and $L T C 4 S$, mRNA expression of PLA2G4A, $A L O X 5$, and $A L O X 5 A P$ had a time effect $(P<0.01)$; however, that effect resulted from a consistent decrease $(P<0.03)$ in expression from 0 to $7 \mathrm{~d}$ regardless of treatment. The expression of $L T A 4 H$ and $A K T 1$ was not affected by diet, time, or their interaction.

Inflammatory Regulators. Main effects of diet, time, and interactions for inflammatory regulator genes 
OSORIO ET AL.
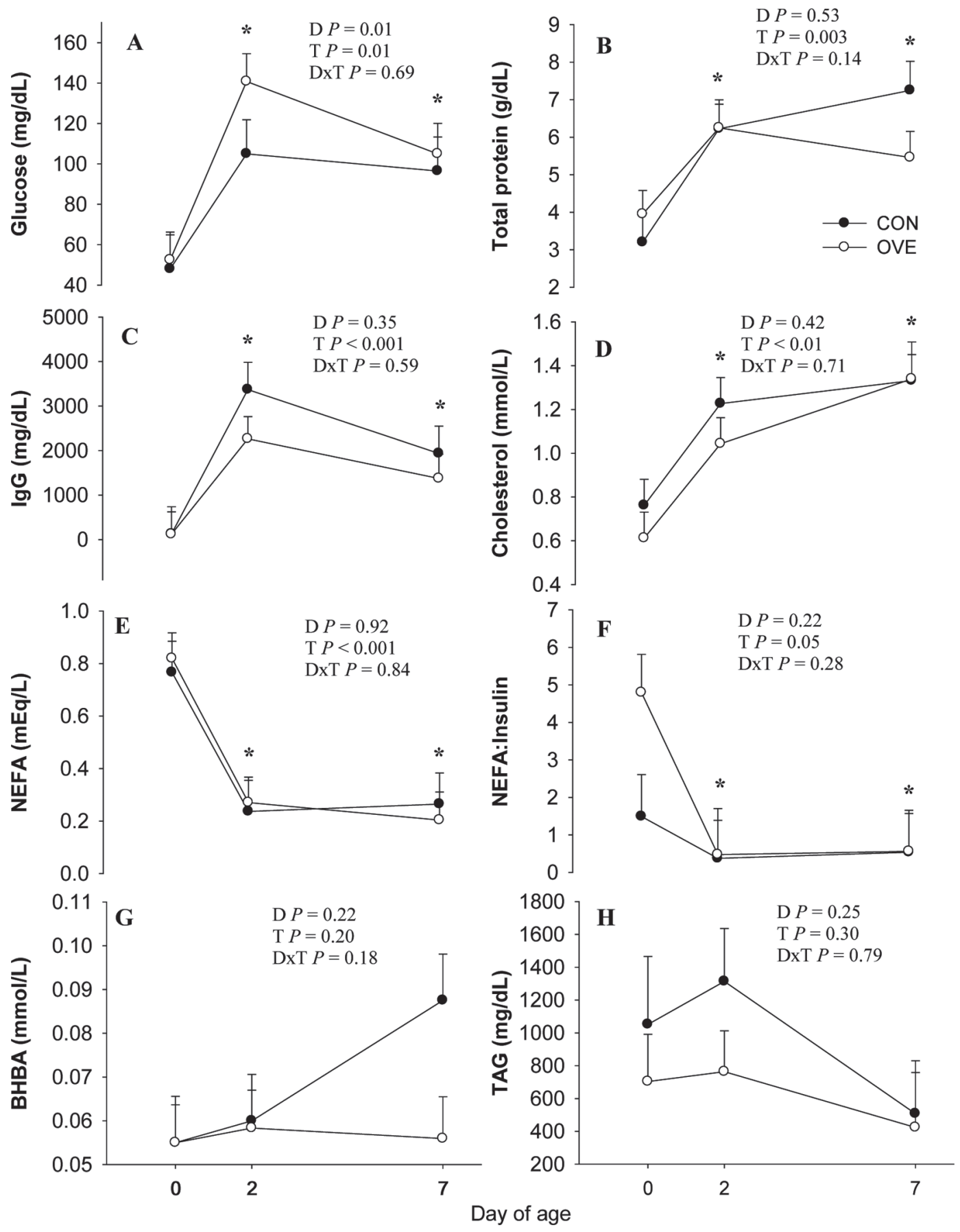

Figure 2. Blood metabolites in calves born to dams fed a conventional diet (CON $=1.24 \mathrm{Mcal} / \mathrm{kg}$ of DM) during the entire dry period or overfed a moderate energy diet $(\mathrm{OVE}=1.47 \mathrm{Mcal} / \mathrm{kg}$ of DM) during the last $21 \mathrm{~d}$ prepartum. Data are from samples at birth (precolostrum; $\mathrm{d}$ $0)$, d 2 (postcolostrum), and d 7 of age. The $P$-values for main effect of diet (D) and time (T) and $\mathrm{D} \times \mathrm{T}$ are shown. Mean separation between time points was evaluated via contrasts: d 0 versus 2 or d 0 versus 7 . Significant differences between times $(P<0.10)$ are denoted by an asterisk. $\mathrm{TAG}=$ triacylglycerol.

are shown in Figure 7. A time effect $(P=0.04)$, similar to $L T C 4 S$, was observed for mRNA expression of $I L 6$ (Figure 7$)$ due to a marked decrease $(P=0.01)$ from 0 to $2 \mathrm{~d}$. Expression of TNF increased modestly over time $(P=0.13)$. The expression of $I L 10, N F K B 1$, and
STAT3 was not affected by diet, time, or their interaction.

Immune Receptors and Adhesion Molecules. Main effects of diet, time, and interactions for immune receptors and adhesion molecule-related genes are 

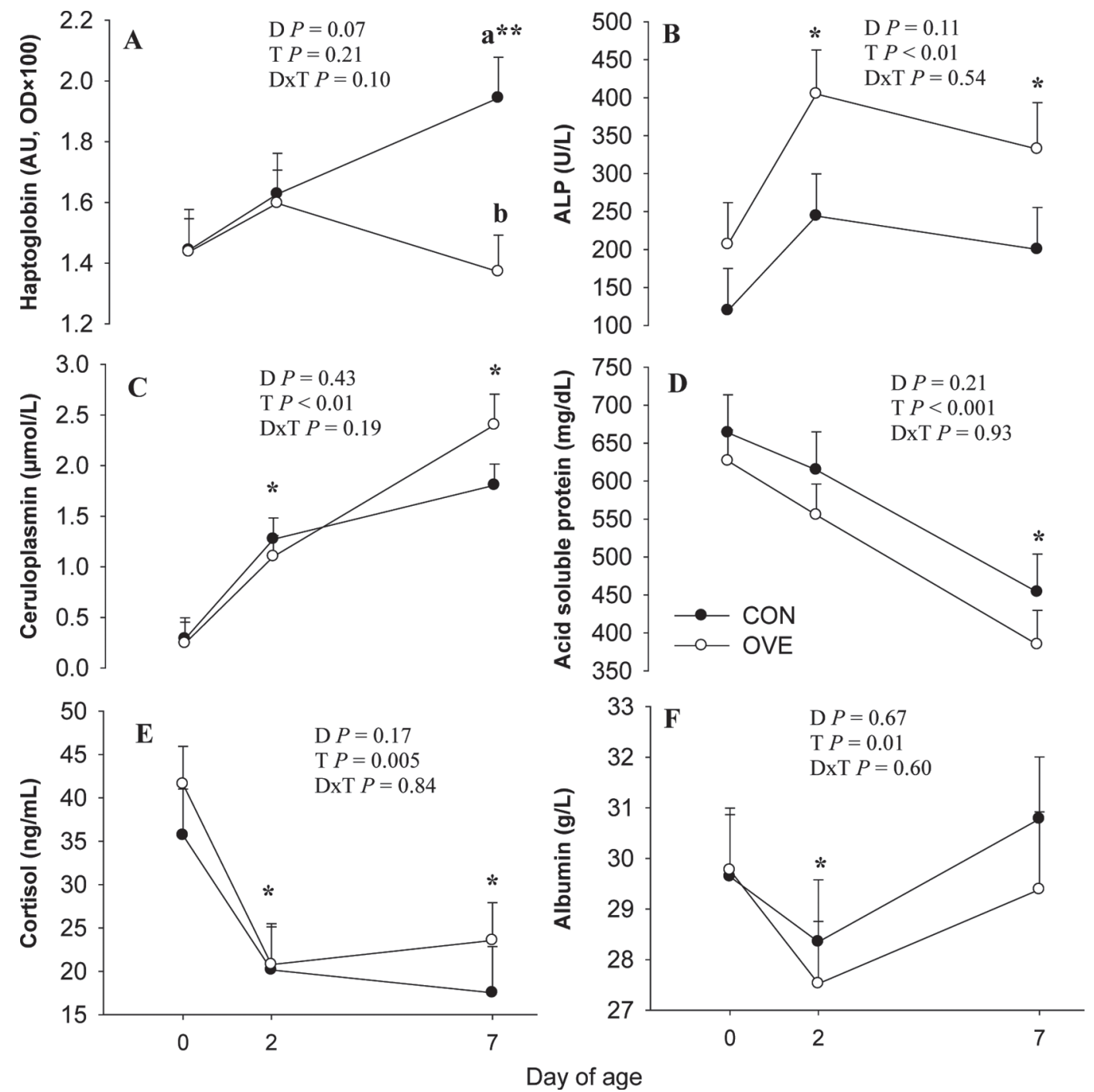

Figure 3. Blood markers immune, stress, and liver function in calves born to dams fed a conventional diet $(\mathrm{CON}=1.24 \mathrm{Mcal} / \mathrm{kg}$ of $\mathrm{DM})$ during the entire dry period or overfed a moderate energy diet $(\mathrm{OVE}=1.47 \mathrm{Mcal} / \mathrm{kg}$ of $\mathrm{DM})$ during the last $21 \mathrm{~d}$ prepartum. Data are from samples at birth (precolostrum; d 0), d 2 (postcolostrum), and d 7 of age. The $P$-values for main effect of diet $(\mathrm{D})$ and time $(\mathrm{T})$ and $\mathrm{D} \times \mathrm{T}$ are shown. Mean separations between $\mathrm{D}$ at the same $\mathrm{T}(P<0.10)$ are denoted with lowercase a or b. Mean separation between time points was evaluated via contrasts: d 0 versus 2 or d 0 versus 7 . Significant differences between times $(P<0.10)$ are denoted by an asterisk, and a tendency $(P=0.12)$ is denoted by a double asterisk. ALP $=$ alkaline phosphatase; OD $=$ optical density.

shown in Figure 8. Expression of TLR 4 was greater $(P$ $=0.08)$ in OVE compared with CON and decreased $(P$ $<0.01$ ) regardless of maternal diet on $\mathrm{d} 2$, after which it remained unchanged. Similar to the pattern observed with TLR4, ALOX5, ALOX5AP, and PLA2G4A, the expression of $I L 1 R 2$ decreased $(P=0.005)$ over time regardless of treatment. In contrast, the expression of $S E L L$ had a time effect $(P<0.04)$ due to an increase over time regardless of treatment. The expression of $H L A-D R A$ and TLR2 was not affected by diet, time, or their interaction.

Nuclear Receptors. Main effects of diet, time, and interactions for long-chain FA-responsive nuclear recep- tors are shown in Figure 9. A lower $(P \leq 0.10)$ mRNA expression of PPARA and PPARD was observed in OVE calves. An overall decrease $(P<0.02)$ in the expression of PPARA, PPARG, and RXRA over the first week of age was observed regardless of treatment. In the case of PPARA, the decrease in expression occurred mainly in CON calves on d 2 compared with d $0(P=0.004)$ and remained low at $\mathrm{d} 7(P=0.002)$, whereas OVE remained unchanged $(P \geq 0.11)$. The overall expression of PPARG followed a similar pattern to PPARA, IL1R2, TLR4, and ALOX5, with lower expression on d $2(P<0.001)$ relative to $0 \mathrm{~d}$ and persisted to be lower on $\mathrm{d} 7(P<0.001)$. However, only the decrease 

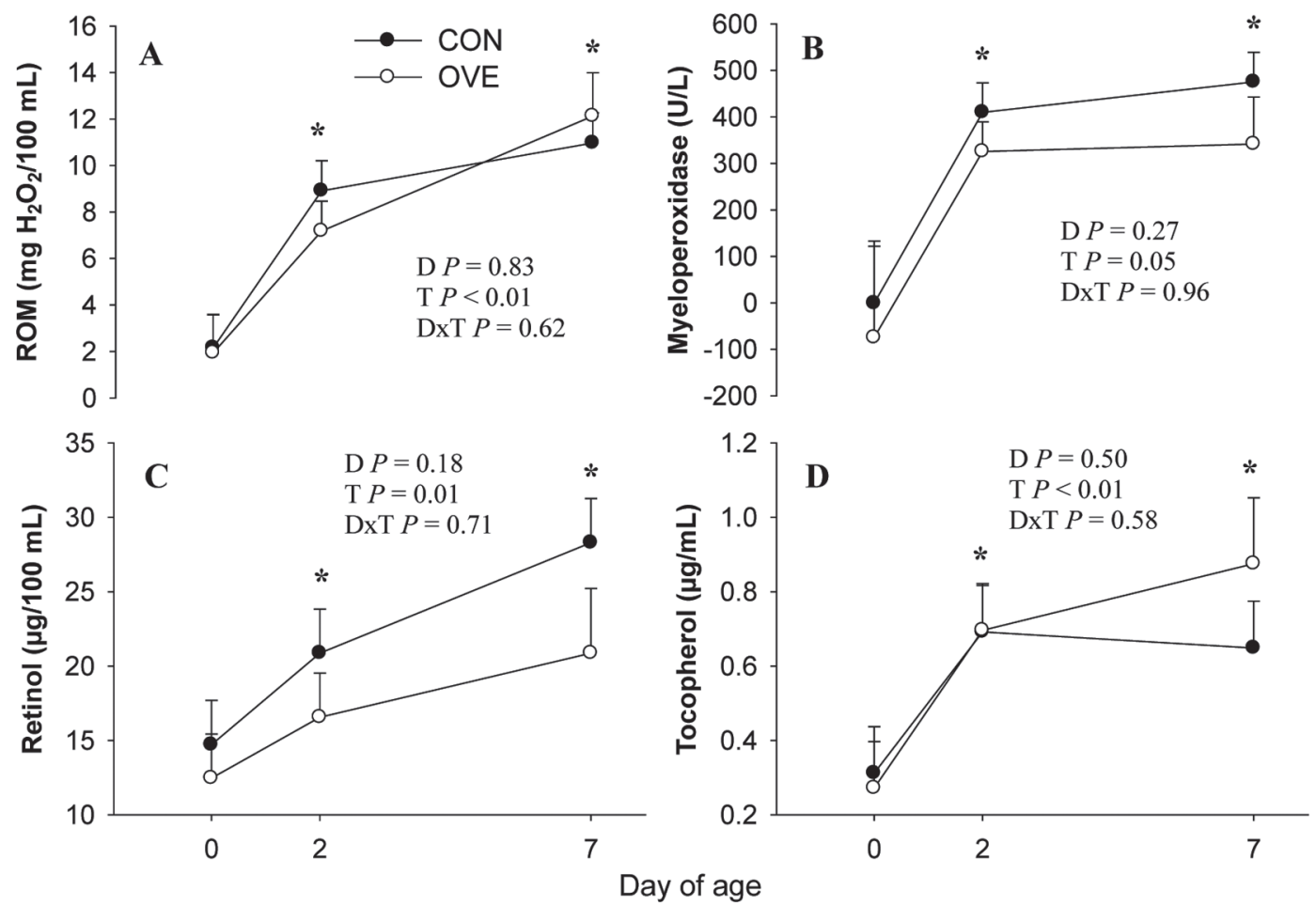

Figure 4. Blood markers related to oxidative stress in calves born to dams fed a conventional diet $(\mathrm{CON}=1.24 \mathrm{Mcal} / \mathrm{kg}$ of $\mathrm{DM})$ during the entire dry period or overfed a moderate energy diet $(\mathrm{OVE}=1.47 \mathrm{Mcal} / \mathrm{kg}$ of DM) during the last $21 \mathrm{~d}$ prepartum. Data are from samples at birth (precolostrum; d 0), d 2 (postcolostrum), and $\mathrm{d} 7$ of age. The $P$-values for main effect of diet (D) and time $(\mathrm{T})$ and $\mathrm{D} \times \mathrm{T}$ are shown. Mean separation between time points was evaluated via contrasts: d 0 versus 2 or d 0 verus 7 . Significant differences between times $(P<0.10)$ are denoted by an asterisk. $\mathrm{ROM}=$ reactive oxygen metabolites.

in PPARG expression was common to $\mathrm{CON}$ and $\mathrm{OVE}$ calves. The expression of $R X R A$ did not change from 0 to $2 \mathrm{~d}(P=0.22)$, but decreased on $\mathrm{d} 7(P=0.005)$.

\section{DISCUSSION}

\section{Metabolic Markers}

Although an effect of handling before blood sampling on biomarkers cannot be discounted, the similar metabolic profiles at precolostrum in OVE and CON calves suggest a similar degree of flow of nutrients from the mother to the calf through the umbilical cord. Even though precolostrum insulin was not significantly $(P=$ $0.35)$ affected by the maternal diet in OVE compared with CON $(0.42 \pm 0.34 \mu \mathrm{g} / \mathrm{L}$ and $1.20 \pm 0.38 \mu \mathrm{g} / \mathrm{L}$, respectively), substantial evidence exists in the literature that greater maternal level of intake during pregnancy might lead to greater insulin levels in the neonate and predispose them to insulin insensitivity (Aerts and van Assche, 1977; Heerwagen et al., 2010).

Postcolostrum metabolic changes on d 2 were likely induced by colostrum intake, either through components in the colostrum or the response of the calf to those components (e.g., insulin, cortisol, prolactin,
IGF-1, and progesterone) are present in colostrum at a wide range of concentrations (Blum and Hammon, 2000). More recent studies also provide evidence of the presence of acute-phase proteins (e.g., HP and serum amyloid A) in colostrum (Reinhardt and Lippolis, 2008). The postcolostrum hormonal and metabolic changes observed on d 2 and 7 might have been driven primarily by the consumption of the low-fat or high-carbohydrate milk replacer. Such responses could partly explain the substantial increase in glucose concentration on d 2 and 7 in comparison to precolostrum levels, which represented a 172 and $117 \%$ increment, respectively.

\section{Adipokines and Hepatokines in Blood}

Regardless of maternal diet, the concentration of leptin before colostrum was approximately $1.9 \mathrm{ng} /$ $\mathrm{mL}$ and was lower than the $5.0 \mathrm{ng} / \mathrm{mL}$ previously observed at birth and before the first meal in dairy calves (Blum et al., 2005). Although the maternal diet did not affect FGF-21 at birth, it was within a range $(1,775 \mathrm{pg} / \mathrm{mL})$ of what has been observed in other studies with mice (Hondares et al., 2010; Yu et al., 2012 ; i.e., approximately $1,500 \mathrm{pg} / \mathrm{mL}$ on $\mathrm{d} 2$ after birth; Figure 1C). 

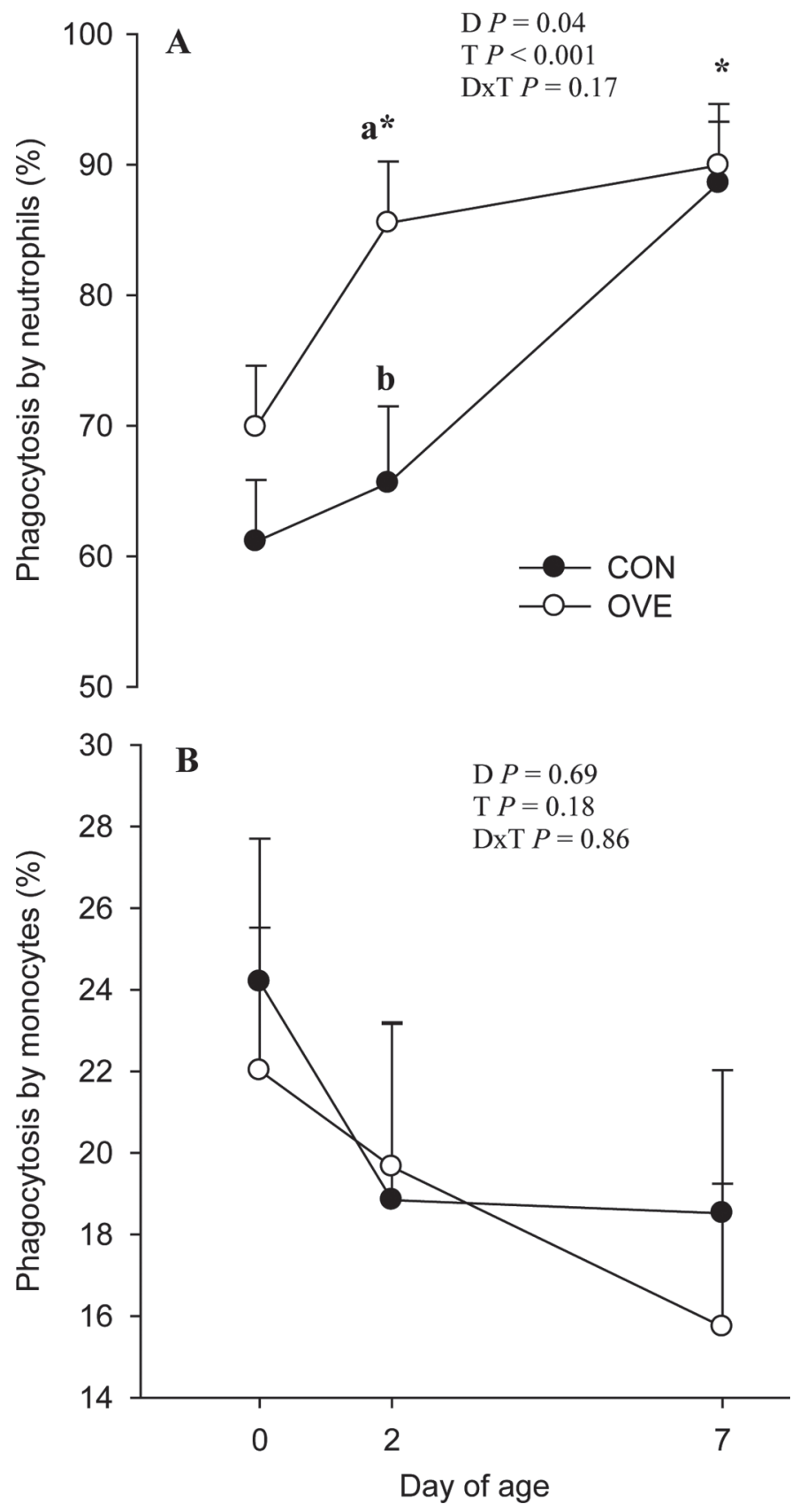

Figure 5. Phagocytic performance of leukocytes and differential analysis of polymorphonuclear leukocytes and monocytes in calves born to dams fed a conventional diet $(\mathrm{CON}=1.24 \mathrm{Mcal} / \mathrm{kg}$ of $\mathrm{DM})$ during the entire dry period or overfed a moderate energy diet (OVE $=1.47 \mathrm{Mcal} / \mathrm{kg}$ of $\mathrm{DM}$ ) during the last $21 \mathrm{~d}$ prepartum. Data are from samples at birth (precolostrum; d 0), d 2 (postcolostrum), and d 7 of age. The $P$-values for main effect of diet (D) and time $(\mathrm{T})$ and $\mathrm{D} \times \mathrm{T}$ are shown. Mean separations between $\mathrm{D}$ at the same $\mathrm{T}(P<0.10)$ are denoted with lowercase a or b. Mean separation between time points was evaluated via contrasts: d 0 versus 2 or d 0 versus 7 . Significant differences between times $(P<0.10)$ are denoted by an asterisk.

\section{Inflammation Markers and Phagocytosis}

The greater concentration of HP in CON compared with OVE calves on $\mathrm{d} 7$ of life was unlikely to be related with colostrum intake. This response is comparable to previous work (Orro et al., 2008) where the highest concentration of plasma HP in dairy calves was observed on d 10 of life. However, it disagrees with data from Bertoni et al. (2009), who observed a peak of HP on $\mathrm{d} 2$ of age, which would agree with the pattern of expression we observed in PMN for IL10. Similar to the liver, the mammary gland produces HP (Hiss et al., 2004) and is a protein found in colostrum (Reinhardt and Lippolis, 2008). Although the ability of colostral HP ingestion to induce hepatic HP synthesis in dairy calves is unknown, this has been observed previously in neonatal swine (Hiss-Pesch et al., 2011). No difference in maternal prepartal serum HP was observed (data not shown), thus, it is unlikely that colostrum HP concentration differed.

Alkaline phosphatase, specifically from neutrophils, increases during inflammatory responses induced by E. coli mastitis (Heyneman and Burvenich, 1992). Interleukin-8, an important chemoattractant, can induce the release of ALP from secondary granules and consequently promote the production of ROM by PMN during chemotaxis (Seguchi and Kobayashi, 2002; Paape et al., 2003). The greater $(P=0.11)$ concentration of ALP in OVE suggest a greater PMN activity and chemotactic environment in these calves, which was consistent with greater phagocytosis. It remains to be determined if the PMN response in OVE calves was related with greater glucose use as has been shown in nonruminants (Healy et al., 2002; Paape et al., 2003; Calder et al., 2007).

\section{PMN Gene Expression}

Inflammatory and Oxidative Stress Enzymes. The increase in SOD2 expression on d 2 regardless of treatment could have been linked with an increase in oxidative stress status, which would partly explain the similar response in percentage phagocytosis observed. It is possible that additional components in colostrum besides carbohydrates might have triggered these differential adaptations in mRNA expression. For instance, it is known that SOD2 can be induced by various stimuli, such as tumor necrosis factor- $\alpha$, IFN $\gamma$, IL-1, and IL-6 (Valdivia et al., 2009), and colostrum contains variable amounts of immune-related proteins (Reinhardt and Lippolis, 2008). The concentration of tumor necrosis factor- $\alpha$ was greatest in first-milking colostrum than subsequent milkings (Blum and Hammon, 2000).

Besides cytokines and chemokines, lipid mediators such as leukotrienes trigger an inflammatory response 
OSORIO ET AL.
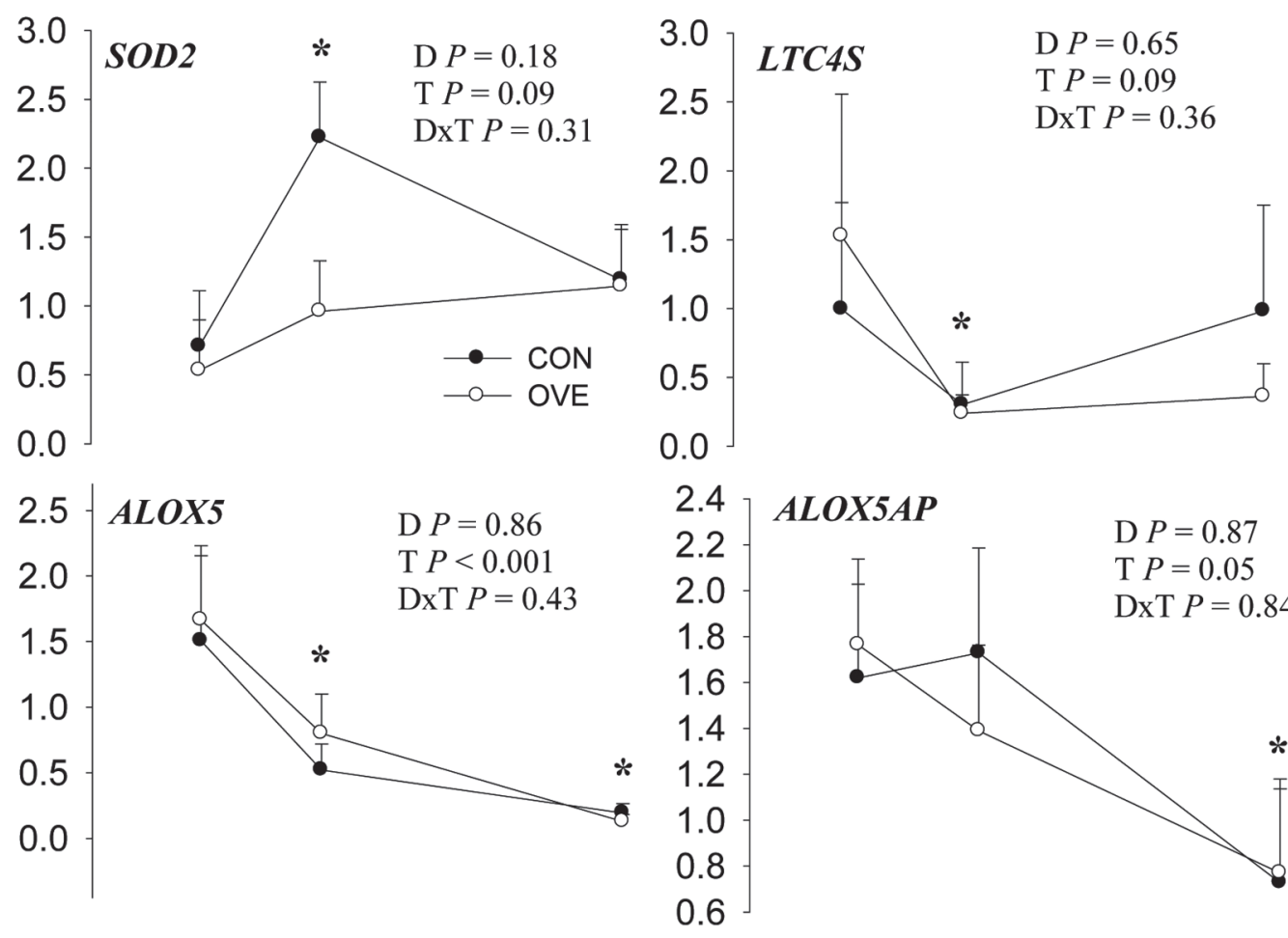

ALOX5AP
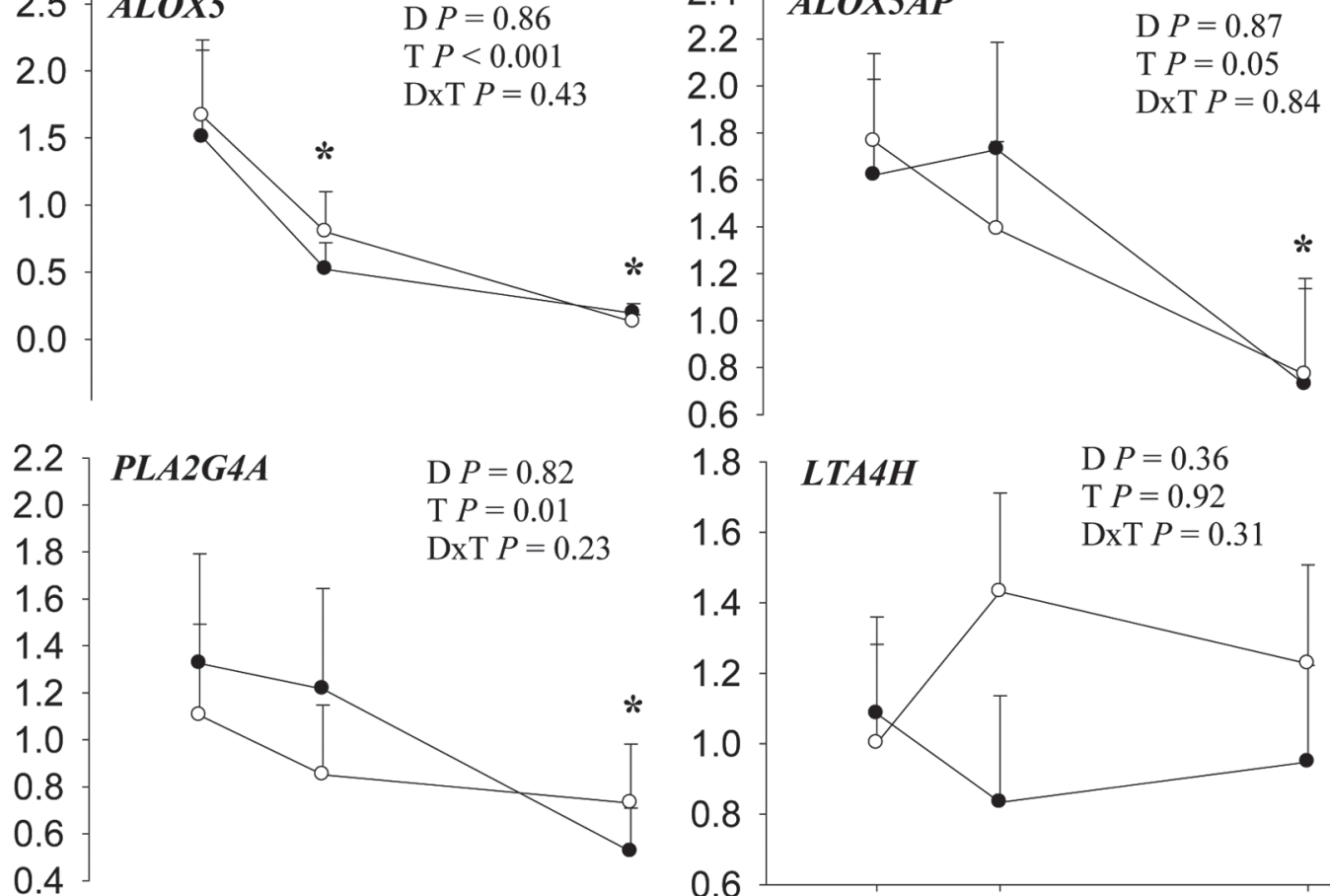

1.8
1.6
1.4
1.2
1.0
0.8
0.6
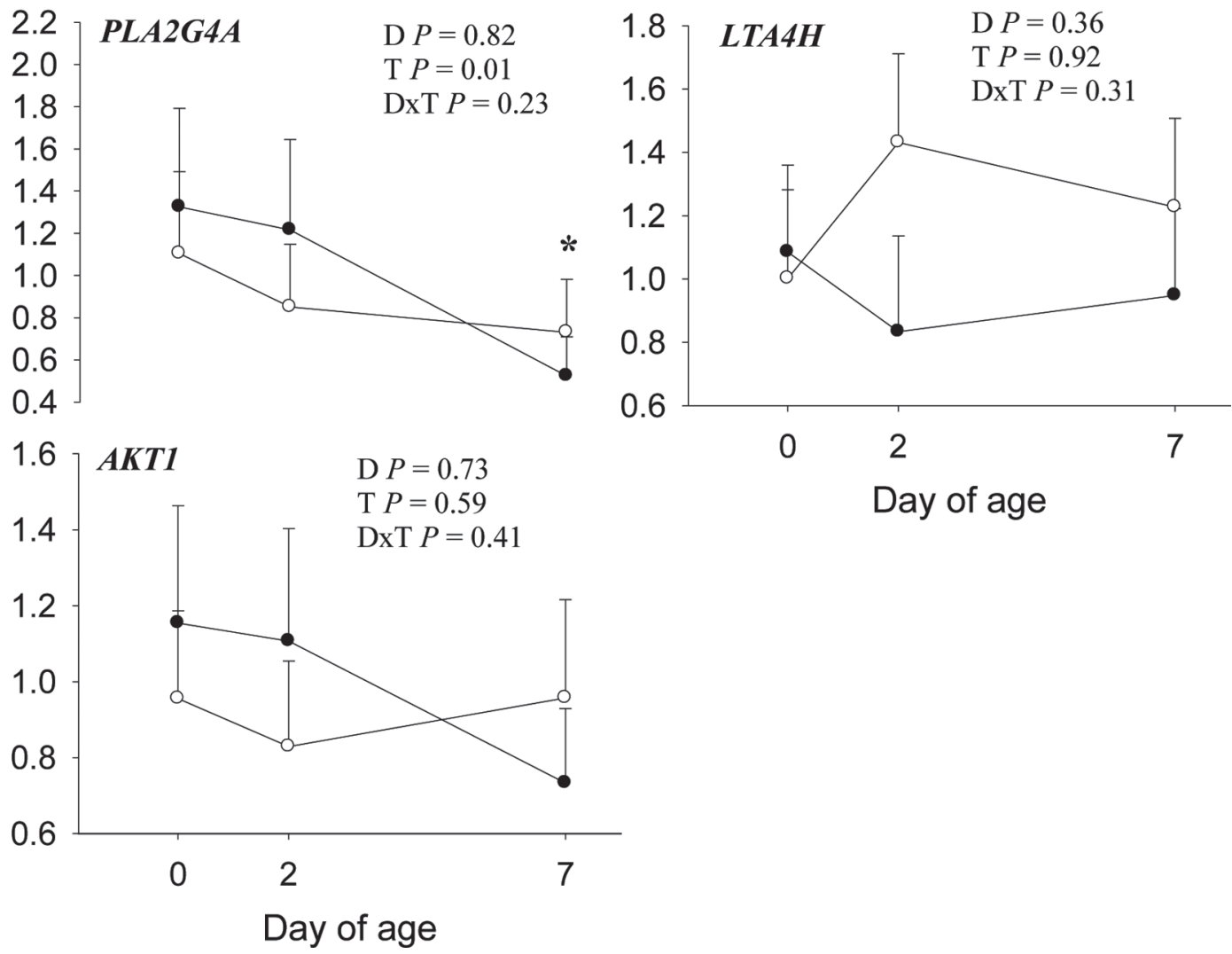

Figure 6. Expression of genes related to oxidative stress (SOD2) and inflammation (PLA2G4A, AKT1, ALOX5, ALOX5AP, LTA4H, and $L T C 4 S)$ in polymorphonuclear leukocytes of calves born to dams fed a conventional diet (CON = $1.24 \mathrm{Mcal} / \mathrm{kg}$ of DM) during the entire dry period or overfed a moderate energy diet $(\mathrm{OVE}=1.47 \mathrm{Mcal} / \mathrm{kg}$ of $\mathrm{DM})$ during the last $21 \mathrm{~d}$ prepartum. Data are from samples at birth (precolostrum; d 0), d 2 (postcolostrum), and d 7 of age. The $P$-values for main effect of diet (D) and time (T) and D $\times \mathrm{T}$ are shown. Mean separation between time points was evaluated via contrasts: d 0 versus 2 or d 0 versus 7 . Significant differences between times $(P<0.10)$ are denoted by an asterisk. 

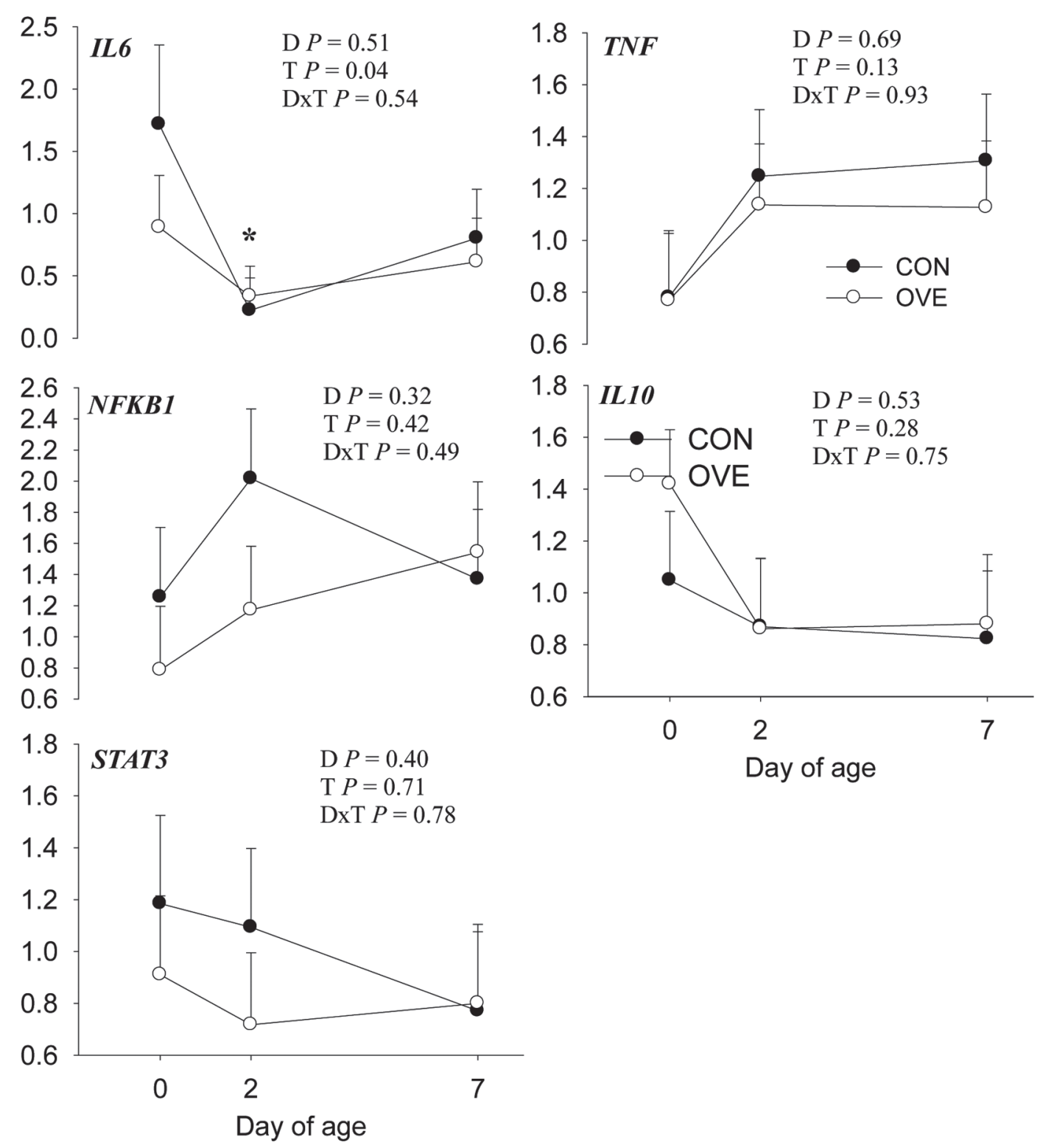

Figure 7. Expression of genes related to pro- (TNF, IL6, STAT3, NFKB1) and anti-inflammatory (IL10) response in polymorphonuclear leukocytes of calves born to dams fed a conventional diet $(\mathrm{CON}=1.24 \mathrm{Mcal} / \mathrm{kg}$ of $\mathrm{DM})$ during the entire dry period or overfed a moderate energy $\operatorname{diet}(\mathrm{OVE}=1.47 \mathrm{Mcal} / \mathrm{kg}$ of $\mathrm{DM})$ during the last $21 \mathrm{~d}$ prepartum. Data are from samples at birth (precolostrum; d 0), d 2 (postcolostrum), and $\mathrm{d} 7$ of age. The $P$-values for main effect of diet $(\mathrm{D})$ and time $(\mathrm{T})$ and $\mathrm{D} \times \mathrm{T}$ are shown. Mean separation between time points was evaluated via contrasts: d 0 versus 2 or d 0 versus 7 . Significant differences between times $(P<0.10)$ are denoted by an asterisk.

to attract leukocytes to sites of bacterial infection (Rubin et al., 2005). The release of arachidonic acid from membrane phospholipids is the first step in the production of leukotrienes, and PLA2G4A mediates this initial step (Leslie, 1997). The gradual downregulation of PLA2G4A, ALOX5, and ALOX5AP in PMN suggested that availability of arachidonic acid for leukotriene A4 synthesis (Haeggström and Funk, 2011) decreased during the neonatal period, potentially indicating a decline in the inflammatory state as the calf adjusted to an extra-uterine environment. Overall, it is likely that leu- kotriene production is greater at birth and decreases as the calf adjusts to the extra-uterine environment.

Inflammatory Regulators. The decrease in IL 6 over the first week of life is consistent with a decrease in leukotriene production-related genes (PLA2G4A, $A L O X 5$, and $A L O X 5 A P$ ), presumably due to a decline in inflammatory conditions after birth. Even though TLR 4 expression, an important activator of the innate immune system, was greater in OVE compared with CON PMN, it was not associated with greater expression of the proinflammatory genes NFKB1 and TNF. 


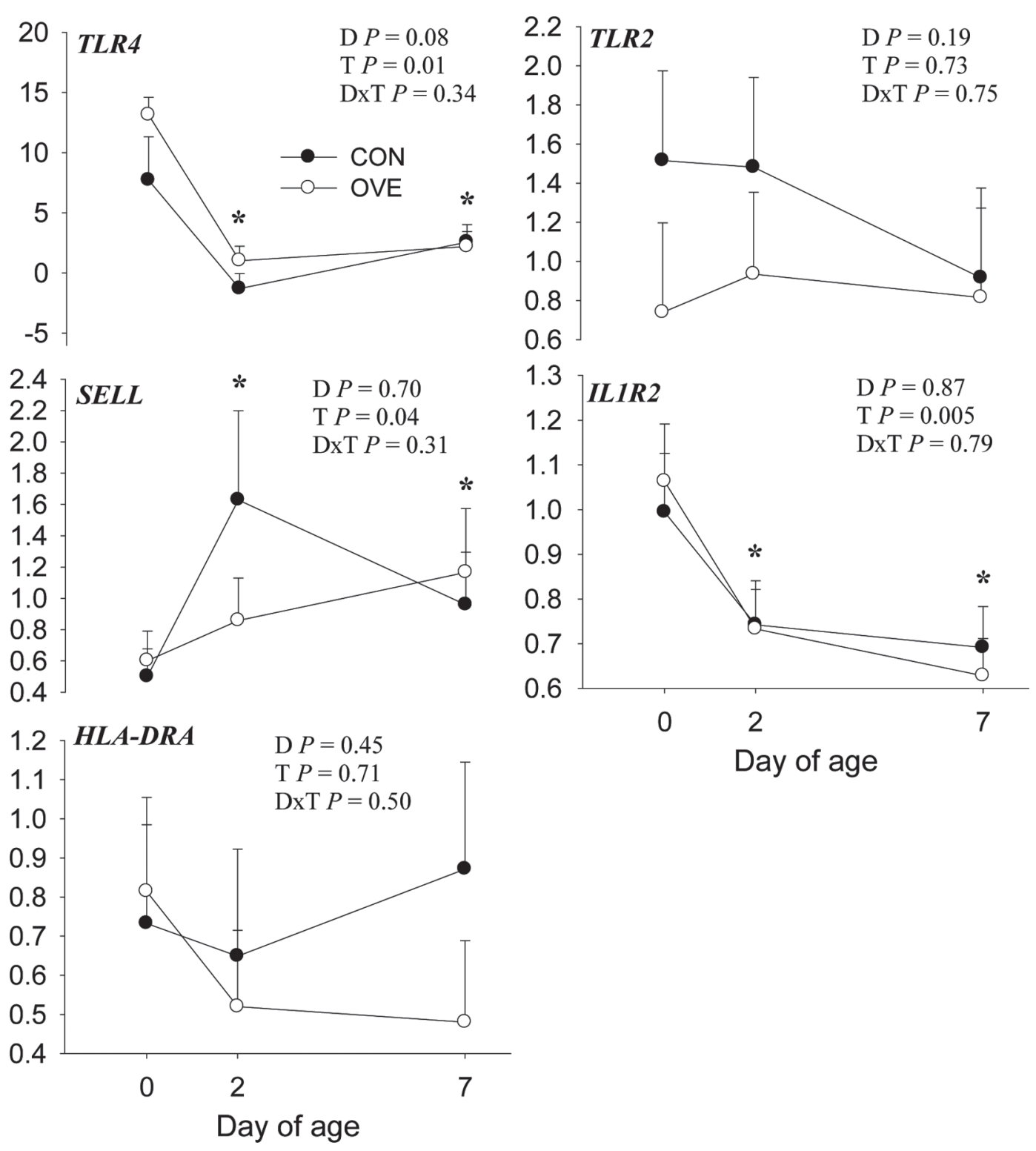

Figure 8. Expression of genes associated with immune-related receptors in polymorphonuclear leukocytes of calves born to dams fed a conventional diet $(\mathrm{CON}=1.24 \mathrm{Mcal} / \mathrm{kg}$ of $\mathrm{DM})$ during the entire dry period or overfed a moderate energy diet $(\mathrm{OVE}=1.47 \mathrm{Mcal} / \mathrm{kg}$ of $\mathrm{DM})$ during the last $21 \mathrm{~d}$ prepartum. Data are from samples at birth (precolostrum; d 0), d 2 (postcolostrum), and d 7 of age. The $P$-values for main effect of diet (D) and time $(\mathrm{T})$ and $\mathrm{D} \times \mathrm{T}$ are shown. Mean separation between time points was evaluated via contrasts: $\mathrm{d} 0$ versus 2 or $\mathrm{d} 0$ versus 7 . Significant differences between times $(P<0.10)$ are denoted by an asterisk.

In fact, a moderate increase $(P=0.13)$ in $T N F$ and no change was observed in NFKB1 over time.

The lack of time effect on STAT3 could have diminished the ability of IL6 to induce this transcription factor (Ling et al., 2004), or perhaps this effect was related to a similar abundance of membrane or soluble IL-6 receptor, which can determine the anti- or proinflammatory activity of this cytokine (Scheller et al., 2011). Besides IL6, other factors might have played a role in the results observed; for example, serum leptin concentration (Figure 1A) has been observed to increase
STAT3 (Bates and Myers, 2004). Consequently, STAT3 could be a reflection of leptin concentration during the same time frame.

Adhesion Molecules. The greater overall TLR4 and blood glucose in OVE compared with CON could have exerted a priming effect, resulting in a greater phagocytosis activity on $\mathrm{d} 2$. The cause of the different $T L R 4$ at birth is not clear, but is potentially important because placenta is known to serve as a selective maternal-fetal barrier against the transmission of microbes. It could be argued that the maternal diet might have 

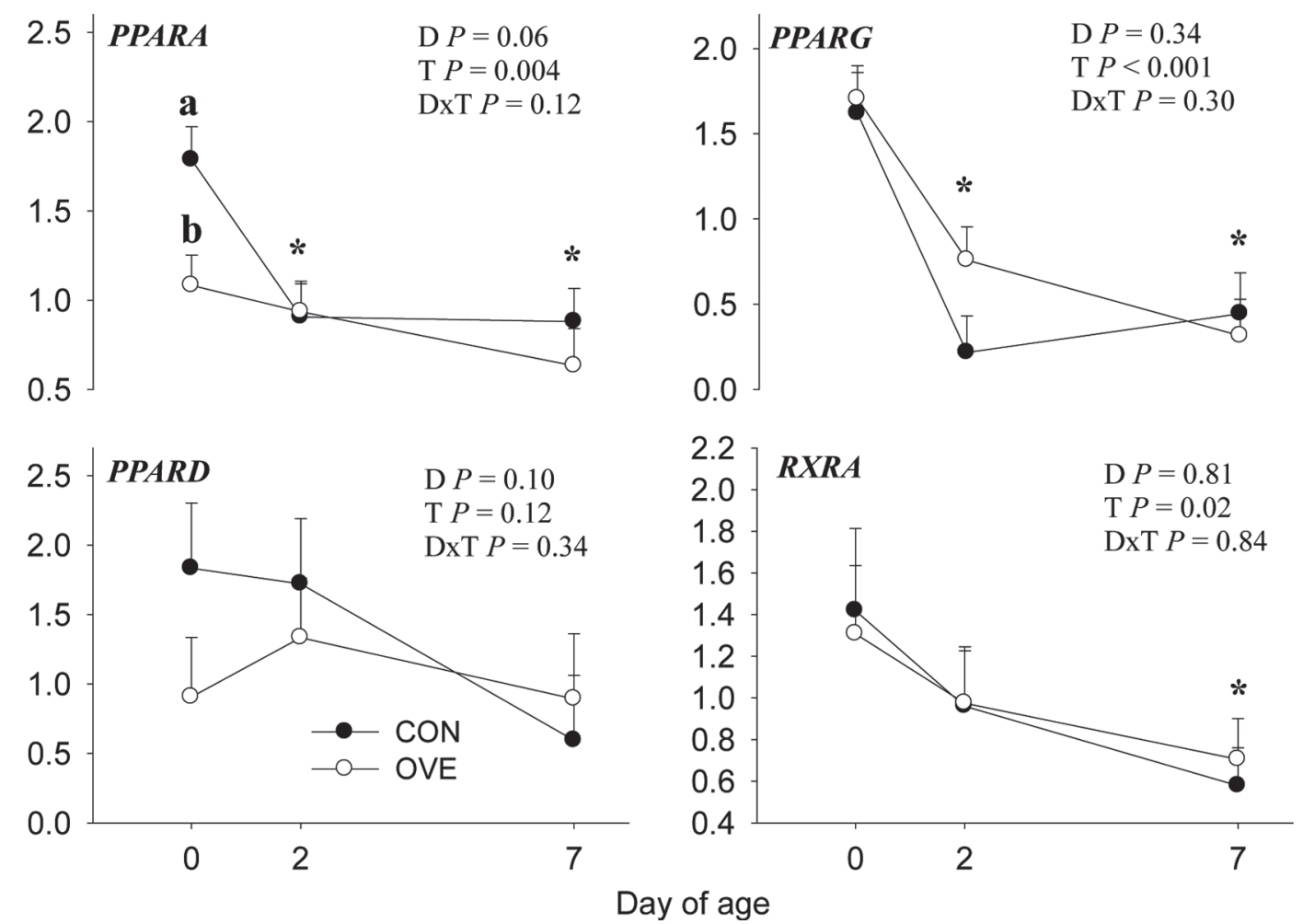

Figure 9. Expression of genes associated with transcription regulation in polymorphonuclear leukocytes from calves born to dams fed a conventional diet $(\mathrm{CON}=1.24 \mathrm{Mcal} / \mathrm{kg}$ of $\mathrm{DM})$ during the entire dry period or overfed a moderate energy diet $(\mathrm{OVE}=1.47 \mathrm{Mcal} / \mathrm{kg}$ of $\mathrm{DM})$ during the last $21 \mathrm{~d}$ prepartum. Data are from samples at birth (precolostrum; d 0), d 2 (postcolostrum), and d 7 of age. The $P$-values for main effect of diet $(\mathrm{D})$ and time $(\mathrm{T})$ and $\mathrm{D} \times \mathrm{T}$ are shown. Mean separations at the same day $(P<0.10)$ are denoted with lowercase a or b. Mean separation between time points was evaluated via contrasts: d 0 versus 2 or d 0 versus 7 . Significant differences between times $(P<0.10)$ are denoted by an asterisk.

affected normal placental function. In fact, supporting data in sheep exists that relates maternal obesity with placental inflammation and the upregulation of TLR4 expression of in placental cotyledons (Zhu et al., 2010).

The lower expression of $S E L L$ at birth compared with d 2 of age might have been related with the higher corresponding concentrations of cortisol (Weber et al., 2001). L-Selectin is an important glycoprotein for adhesion of leukocytes to endothelial cells (Abdelrahman et al., 2005). The marked increase in SELL expression on d 2 of age likely reflected the potential for immunerelated proteins in colostrum to trigger inflammation and prime the innate immune responses.

The sharp decrease in the expression of IL1R2 during the first week of age might have been related with a greater need to mount anti-inflammatory responses at birth, a response that helps truncate IL-1 signaling in nonruminants (Hagiwara et al., 2005). The latter is correlated with decreased concentration of IL1R2 in colostrum than mature milk (Hagiwara et al., 2005).

Nuclear Receptors. In nonruminants, PPARA regulates hepatic FA oxidation and ketogenesis at the transcriptional level, and initiation of thermoregulation in the neonate via upregulation of FGF-21 mRNA and protein (Hondares et al., 2010). Independently of the role of PPARA in PMN, it has been observed that blood NEFA is negatively correlated with immune responses (Calder et al., 1990; Moyes et al., 2009). However, the fact that OVE had a greater NEFA to insulin ratio at birth but lower PPARA and similar RXRA expression compared with CON calves was suggestive of either a lack of use of NEFA by PMN as fuels, an inhibition of NEFA use by PMN (e.g., insulin insensitivity), or a lack of a role of PPARA in PMN when cows were fed OVE. The latter seems to contrast with greater PPARA in CON calves and the marked decrease after $\mathrm{d} 2$ of age. That response, along with lower PMN phagocytosis, could indicate that the negative effects of NEFA can be mediated via activation of PPARA, consequently inducing an anti-inflammatory response, such as lower PMN activity.

Similar to PPARA, PPARD has been associated with anti-inflammatory activity in PMN by negatively regulating the expression of proinflammatory genes 
induced in response to macrophage differentiation and activation (von Knethen and Brune, 2003). Thus, it is conceivable that both PPARA and PPARD worked in concert to reduce inflammatory conditions in $\mathrm{CON}$ calves, which are commonly present at birth. These data suggest a lower anti-inflammatory state in OVE than CON cows at birth, which agrees with the marked level of ceruloplasmin on $\mathrm{d} 7$ (as well as the lower level of albumin and retinol). Overexpression of TLR4 in OVE calves at birth suggests antagonism between PPAR and TLR genes and, in fact, PPARA has been observed to modulate the $T L R$ pathway in diseased states (Ding et al., 2013). Further studies should help clarify the role of $P P A R$ in PMN biology, including potential anti-inflammatory roles (e.g., PPARA activation suppresses the expression of STAT3 in rodent hepatocytes; Stienstra et al., 2007).

\section{CONCLUSIONS}

In summary, calf body mass at birth provided evidence that maternal overfeeding of energy during late gestation elicited developmental effects that could have played a role in some of the physiological responses of the newborn calf at the metabolic, immunological, and transcriptomic level. The response of calves to colostrum feeding also suggested potential effects of overfeeding at the level of the mammary gland. Thus, alterations of the endocrine environment in utero and the colostrum nutrient composition induced by maternal energy overfeeding prepartum can affect metabolic and immune responses of the neonatal calf. From a management standpoint, these data suggest that it might be feasible to design nutrient supplements to compliment colostrum in a way that metabolic and immunologic capability of the calf is improved. Additional research in this area seems warranted.

\section{ACKNOWLEDGMENTS}

The authors thank Peng Ji (Miner Institute, Chazy, NY) for his assistance with cow husbandry and Guido Invernizzi (University of Milan, Italy) for his assistance in the laboratory. The help of the entire staff at the University of Illinois Dairy Research farm is gratefully acknowledged.

\section{REFERENCES}

Abdelrahman, M., A. Sivarajah, and C. Thiemermann. 2005. Beneficial effects of PPAR-gamma ligands in ischemia-reperfusion injury, inflammation and shock. Cardiovasc. Res. 65:772-781.

Aerts, L., and F. A. van Assche. 1977. Rat foetal endocrine pancreas in experimental diabetes. J. Endocrinol. 73:339-346.
Bates, S. H., and M. G. Myers. 2004. The role of leptin $\rightarrow$ STAT3 signaling in neuroendocrine function: An integrative perspective. J. Mol. Med. (Berl.) 82:12-20.

Bertoni, G., A. Ferrari, A. Gubbiotti, and E. Trevisi. 2009. Blood indices calves: Relationship with mother values and changes in the first days of life. Ital. J. Anim. Sci. 8(Suppl. 2):595-597.

Bionaz, M., E. Trevisi, L. Calamari, F. Librandi, A. Ferrari, and G. Bertoni. 2007. Plasma paraoxonase, health, inflammatory conditions, and liver function in transition dairy cows. J. Dairy Sci. 90:1740-1750.

Blum, J. W. 2006. Nutritional physiology of neonatal calves. J. Anim. Physiol. Anim. Nutr. (Berl.) 90:1-11.

Blum, J. W., and H. Hammon. 2000. Colostrum effects on the gastrointestinal tract, and on nutritional, endocrine and metabolic parameters in neonatal calves. Livest. Prod. Sci. 66:151-159.

Blum, J. W., Y. Zbinden, H. M. Hammon, and Y. Chilliard. 2005 Plasma leptin status in young calves: Effects of pre-term birth, age, glucocorticoid status, suckling, and feeding with an automatic feeder or by bucket. Domest. Anim. Endocrinol. 28:119-133.

Bradley, P. P., D. A. Priebat, R. D. Christensen, and G. Rothstein. 1982. Measurement of cutaneous inflammation: Estimation of neutrophil content with an enzyme marker. J. Invest. Dermatol. 78:206-209.

Calder, P. C., J. A. Bond, D. J. Harvey, S. Gordon, and E. A. Newsholme. 1990. Uptake and incorporation of saturated and unsaturated fatty acids into macrophage lipids and their effect upon macrophage adhesion and phagocytosis. Biochem. J. 269:807-814.

Calder, P. C., G. Dimitriadis, and P. Newsholme. 2007. Glucose metabolism in lymphoid and inflammatory cells and tissues. Curr. Opin. Clin. Nutr. Metab. Care 10:531-540.

Ding, J. L., Z. G. Zhou, X. Y. Zhou, B. Zhou, L. Wang, R. Wang, L. Zhan, X. F. Sun, and Y. Li. 2013. Attenuation of acute pancreatitis by peroxisome proliferator-activated receptor-alpha in rats: The effect on toll-like receptor signaling pathways. Pancreas 42:114-122. http://dx.doi.org/10.1097/MPA.0b013e3182550cc4.

Farley, D. M., J. Choi, D. J. Dudley, C. Li, S. L. Jenkins, L. Myatt, and P. W. Nathanielsz. 2010. Placental amino acid transport and placental leptin resistance in pregnancies complicated by maternal obesity. Placenta 31:718-724.

Gao, F., Y. C. Liu, Z. H. Zhang, C. Z. Zhang, H. W. Su, and S. L. Li. 2012. Effect of prepartum maternal energy density on the growth performance, immunity, and antioxidation capability of neonatal calves. J. Dairy Sci. 95:4510-4518.

Haeggström, J. Z., and C. D. Funk. 2011. Lipoxygenase and leukotriene pathways: Biochemistry, biology, and roles in disease. Chem. Rev. 111:5866-5898.

Hagiwara, K., K. Kitajima, H. Yamanaka, R. Kirisawa, and H. Iwai. 2005. Development of a sandwich ELISA assay for measuring bovine soluble type II IL-1 receptor (IL1R2) concentration in serum and milk. Cytokine 32:132-136.

Hayirli, A., D. H. Keisler, L. Doepel, and H. Petit. 2011. Peripartum responses of dairy cows to prepartal feeding level and dietary fatty acid source. J. Dairy Sci. 94:917-930.

Healy, D. A., R. W. Watson, and P. Newsholme. 2002. Glucose, but not glutamine, protects against spontaneous and anti-Fas antibody-induced apoptosis in human neutrophils. Clin. Sci. (Lond.) 103:179-189.

Heerwagen, M. J., M. R. Miller, L. A. Barbour, and J. E. Friedman. 2010. Maternal obesity and fetal metabolic programming: A fertile epigenetic soil. Am. J. Physiol. Regul. Integr. Comp. Physiol. 299:R711-R722.

Heyneman, R., and C. Burvenich. 1992. Kinetics and characteristics of bovine neutrophil alkaline phosphatase during acute Escherichia coli mastitis. J. Dairy Sci. 75:1826-1834.

Hiss, S., M. Mielenz, R. M. Bruckmaier, and H. Sauerwein. 2004. Haptoglobin concentrations in blood and milk after endotoxin challenge and quantification of mammary Hp mRNA expression. J. Dairy Sci. 87:3778-3784.

Hiss-Pesch, S., F. Daniel, S. Dunkelberg-Denk, M. Mielenz, and H. Sauerwein. 2011. Transfer of maternal haptoglobin to suckling piglets. Vet. Immunol. Immunopathol. 144:104-110. 
Hondares, E., M. Rosell, F. J. Gonzalez, M. Giralt, R. Iglesias, and F. Villarroya. 2010. Hepatic FGF21 expression is induced at birth via PPARalpha in response to milk intake and contributes to thermogenic activation of neonatal brown fat. Cell Metab. 11:206-212.

Hulbert, L. E., C. J. Cobb, J. A. Carroll, and M. A. Ballou. 2011. Effects of changing milk replacer feedings from twice to once daily on Holstein calf innate immune responses before and after weaning. J. Dairy Sci. 94:2557-2565.

Janovick, N. A., Y. R. Boisclair, and J. K. Drackley. 2011. Prepartum dietary energy intake affects metabolism and health during the periparturient period in primiparous and multiparous Holstein cows. J. Dairy Sci. 94:1385-1400.

Ji, P., J. S. Osorio, J. K. Drackley, and J. J. Loor. 2012. Overfeeding a moderate energy diet prepartum does not impair bovine subcutaneous adipose tissue insulin signal transduction and induces marked changes in peripartal gene network expression. J. Dairy Sci. 95:4333-4351.

Johnson, J. L., S. M. Godden, T. Molitor, T. Ames, and D. Hagman. 2007. Effects of feeding heat-treated colostrum on passive transfer of immune and nutritional parameters in neonatal dairy calves. J. Dairy Sci. 90:5189-5198.

Kadegowda, A. K., M. Bionaz, B. Thering, L. S. Piperova, R. A. Erdman, and J. J. Loor. 2009. Identification of internal control genes for quantitative polymerase chain reaction in mammary tissue of lactating cows receiving lipid supplements. J. Dairy Sci. 92:2007-2019.

Leslie, C. C. 1997. Properties and regulation of cytosolic phospholipase A2. J. Biol. Chem. 272:16709-16712.

Ling, P. R., R. J. Smith, S. Kie, P. Boyce, and B. R. Bistrian. 2004. Effects of protein malnutrition on IL-6-mediated signaling in the liver and the systemic acute-phase response in rats. Am. J. Physiol. Regul. Integr. Comp. Physiol. 287:R801-R808.

Moyes, K. M., J. K. Drackley, D. E. Morin, and J. J. Loor. 2010. Greater expression of TLR2, TLR4, and IL6 due to negative energy balance is associated with lower expression of HLA-DRA and HLA-A in bovine blood neutrophils after intramammary mastitis challenge with Streptococcus uberis. Funct. Integr. Genomics 10:53-61.

Moyes, K. M., T. Larsen, N. C. Friggens, J. K. Drackley, and K. L. Ingvartsen. 2009. Identification of potential markers in blood for the development of subclinical and clinical mastitis in dairy cattle at parturition and during early lactation. J. Dairy Sci. 92:5419-5428.

Newbern, D., and M. Freemark. 2011. Placental hormones and the control of maternal metabolism and fetal growth. Curr. Opin. Endocrinol. Diabetes Obes. 18:409-416.

Orro, T., S. Jacobsen, J. P. LePage, T. Niewold, S. Alasuutari, and T. Soveri. 2008. Temporal changes in serum concentrations of acute phase proteins in newborn dairy calves. Vet. J. 176:182-187.

Paape, M. J., D. D. Bannerman, X. Zhao, and J. W. Lee. 2003. The bovine neutrophil: Structure and function in blood and milk. Vet. Res. 34:597-627.

Piantoni, P., M. Bionaz, D. E. Graugnard, K. M. Daniels, R. M. Akers, and J. J. Loor. 2008. Gene expression ratio stability evaluation in prepubertal bovine mammary tissue from calves fed different milk replacers reveals novel internal controls for quantitative polymerase chain reaction. J. Nutr. 138:1158-1164.

Quigley, J. D. 3rd, and J. J. Drewry. 1998. Nutrient and immunity transfer from cow to calf pre- and postcalving. J. Dairy Sci. 81:2779-2790.
Quigley, J. D. 3rd, C. J. Kost, and T. M. Wolfe. 2002. Absorption of protein and $\operatorname{IgG}$ in calves fed a colostrum supplement or replacer. J. Dairy Sci. 85:1243-1248.

Rabelo, E., R. L. Rezende, S. J. Bertics, and R. R. Grummer. 2003. Effects of transition diets varying in dietary energy density on lactation performance and ruminal parameters of dairy cows. J. Dairy Sci. 86:916-925.

Reinhardt, T. A., and J. D. Lippolis. 2008. Developmental changes in the milk fat globule membrane proteome during the transition from colostrum to milk. J. Dairy Sci. 91:2307-2318.

Rubin, B. B., G. P. Downey, A. Koh, N. Degousee, F. Ghomashchi, L. Nallan, E. Stefanski, D. W. Harkin, C. Sun, B. P. Smart, T. F. Lindsay, V. Cherepanov, E. Vachon, D. Kelvin, M. Sadilek, G. E. Brown, M. B. Yaffe, J. Plumb, S. Grinstein, M. Glogauer, and M. H. Gelb. 2005. Cytosolic phospholipase A2-alpha is necessary for platelet-activating factor biosynthesis, efficient neutrophil-mediated bacterial killing, and the innate immune response to pulmonary infection: cPLA2-alpha does not regulate neutrophil NADPH oxidase activity. J. Biol. Chem. 280:7519-7529.

Scheller, J., A. Chalaris, D. Schmidt-Arras, and S. Rose-John. 2011. The pro- and anti-inflammatory properties of the cytokine interleukin-6. Biochim. Biophys. Acta 1813:878-888.

Seguchi, H., and T. Kobayashi. 2002. Study of NADPH oxidase-activated sites in human neutrophils. J. Electron Microsc. (Tokyo) 51:87-91.

Stienstra, R., S. Mandard, N. S. Tan, W. Wahli, C. Trautwein, T. A. Richardson, E. Lichtenauer-Kaligis, S. Kersten, and M. Muller. 2007. The Interleukin-1 receptor antagonist is a direct target gene of PPARalpha in liver. J. Hepatol. 46:869-877.

Valdivia, A., S. Perez-Alvarez, J. D. Aroca-Aguilar, I. Ikuta, and J. Jordan. 2009. Superoxide dismutases: A physiopharmacological update. J. Physiol. Biochem. 65:195-208.

von Knethen, A., and B. Brune. 2003. PPARgamma-An important regulator of monocyte/macrophage function. Arch. Immunol. Ther. Exp. (Warsz.) 51:219-226.

Wallace, J. M., D. A. Bourke, R. P. Aitken, and M. A. Cruickshank. 1999. Switching maternal dietary intake at the end of the first trimester has profound effects on placental development and fetal growth in adolescent ewes carrying singleton fetuses. Biol. Reprod. 61:101-110.

Wang, J., H. Ma, C. Tong, H. Zhang, G. B. Lawlis, Y. Li, M. Zang, J. Ren, M. J. Nijland, S. P. Ford, P. W. Nathanielsz, and J. Li. 2010. Overnutrition and maternal obesity in sheep pregnancy alter the JNK-IRS-1 signaling cascades and cardiac function in the fetal heart. FASEB J. 24:2066-2076.

Weber, P. S., S. A. Madsen, G. W. Smith, J. J. Ireland, and J. L. Burton. 2001. Pre-translational regulation of neutrophil L-selectin in glucocorticoid-challenged cattle. Vet. Immunol. Immunopathol. 83:213-240.

Weber, P. S., S. A. Madsen-Bouterse, G. J. Rosa, S. Sipkovsky, X. Ren, P. E. Almeida, R. Kruska, R. G. Halgren, J. L. Barrick, and J. L. Burton. 2006. Analysis of the bovine neutrophil transcriptome during glucocorticoid treatment. Physiol. Genomics 28:97-112.

Yu, J., B. Yu, H. Jiang, and D. Chen. 2012. Conjugated linoleic acid induces hepatic expression of fibroblast growth factor 21 through PPAR-alpha. Br. J. Nutr. 107:461-465.

Zhu, M. J., M. Du, P. W. Nathanielsz, and S. P. Ford. 2010. Maternal obesity up-regulates inflammatory signaling pathways and enhances cytokine expression in the mid-gestation sheep placenta. Placenta 31:387-391. 